\title{
LOWER CRETACEOUS CARBONATE DEPOSITS FROM THE DEREZNA BOREHOLE (CARPATHO-BALKKANIDES, EASTERN SERBIA) AND REMARKS ON SOME DASYCLADALEAN ALGAE
}

\author{
Ioan I. Bucur ${ }^{1 *}$, Divna Jovanović2, Rajka Radoičić ${ }^{3}$, Milan $\operatorname{Sudar}^{4} \&$ Cristian Victor Mircescu ${ }^{1}$
}

Received: 28 May 2020 / Accepted: 10 July 2020 / Published online: 25 July 2020

\begin{abstract}
An exploratory borehole cross-cutting Miocene deposits near Derezna (south of Kučevo town, Eastern Serbia) has intercepted Lower Cretaceous carbonate rocks in its lower part. The identified microfacies and micropaleontological associations indicate a Barremian age for these limestones. Among the identified dasycladalean algae, Salpingoporella patruliusi Bucur, a generally rare alga, is here recorded in relatively high abundance. Its occurrence is recorded for the first time in Serbia. Similiclypeina aff. somalica (Conrad et al.) is another dasycladalean species identified for the first time in the region. Its presence allows us to make some remarks concerning the two genera Similiclypeina and Piriferella.
\end{abstract}

Keywords: Lower Cretaceous, Dasycladales, Taxonomy, Carpatho-Balkanides, Eastern Serbia

\section{INTRODUCTION. GEOLOGICAL FRAMEWORK}

The investigated area of Eastern Serbia belongs to the Carpatho-Balkanides which extend from the Danube to the north, to the Serbian/Bulgarian border to the south. According to Karamata \& Krstić (1996) this area represents the Kučaj terrane, a large Alpine geotectonic unit (Fig. 1). According to Kräutner \& Krstić (2002), this area is part of the Getic units which include the Getic nappe north of the Danube, and its continuation in the Kučaj-Ljubaš and Sredna Gora zones in Eastern Serbia, south of the Danube (Fig. 2).

The Derezna borehole was drilled in the 1990s in Miocene sediments for investigations related to coal deposits in the region. Besides Derezna, occurrences of coals are known also from the villages Rakova Bara and Radenka located north of Kučevo town (Fig. 1). The Miocene sediments consist of marlstones, claystones with coal, conglomerates, and clays. They are surrounded by sediments of Early Cretaceous age (Berriasian to Albian; Kalenić et al., 1980, Fig. 3). Rock samples collected from the sedimentary succession indicate the presence of carbonate deposits in the lower part of the borehole. Their study represents the object of this paper.

\section{MATERIAL AND METHODS}

Eight limestone samples were collected from carbonate deposits recovered in the Derezna borehole and an equivalent number of thin sections were prepared. They are labelled RR4834 to RR4841 and are deposited in the I.I. Bucur collection in the Department of Geology, Babeș-Bolyai University, Cluj-Napoca. Microscope studies were performed with a Zeiss Stemi 2000C stereomicroscope and a Carl Zeiss Axioscope petrographic microscope. For microphotographs a Canon Power Shot A640 digital camera was used. Carbonate rock description follows the textural classification of Dunham (1962).

\section{MICROFACIES AND MICROPALEON- TOLOGICAL ASSEMBLAGES}

Eight samples were recovered from limestone deposits drilled by the borehole, after crossing the Miocene deposits. The petrographic spectrum is dominated by muddy facies (wackestone, wackestone-packstone or packstone) and subordinate packstone-grainstone or coarse grainstone (Fig. 4a-h). All the facies varieties contain calcareous algae (mainly dasycladaleans, rare udoteaceans or rodophyceans). Other bioclasts include foraminifera, bivalve, gastropod, echinoderm, bryozoan, and brachiopod fragments. The calcareous algae assemblage contains the following species: Salpingoporella patruliusi Bucur (Fig. 5a-f), Salpingoporella muehlbergii (Lorenz) [Fig. 6a-c, f, $\mathrm{g}(\mathrm{Sm}), \quad \mathrm{h}(\mathrm{Sm}), \quad \mathrm{i}(\mathrm{Sm}), \quad \mathrm{j}(\mathrm{Sm}) ; \quad$ Fig. $\quad 7 \mathrm{~m}(\mathrm{Sm})]$, Salpingoporella cf. muehlbergii (Fig. 6d, e), Similiclypeina aff. somalica Conrad, Peybernès \& Masse [Fig. 6h(Ss)], Similiclypeina conradi Bucur [Fig. 6i(Sc), Fig. 7k], Milanovicella? sp. (Fig. 7a), Korkyrella texana Sokač (Fig. 7b, c), Salpingoporella biokovensis Sokač \& Velić (Fig. 7d), Clypeina div. sp. (Fig. 7e-h), Actinoporella podolica (Alth) [Fig. 7i, j, 1, m (Ap)], Arabicodium? sp. (Fig. 6k) and Sporolithon rude (Lemoine) [Fig. 6j (Sr)].

\footnotetext{
${ }^{1}$ Babeş-Bolyai University, Department of Geology and Center for Integrated Geological Studies, M. Kogălniceanu 1, 400084 Cluj-Napoca, Romania, ioan.bucur@ubbcluj.ro; cristianvictormircescu@ hotmail.com.

${ }^{2}$ Geological Survey of Serbia, Rovinjska 12,11000 Beograd, Serbia, djdivna@gmail.com

${ }^{3}$ Kralja Petra I, 38, 11158 Beograd, Serbia, rajkaradoicic@gmail.com

${ }^{4}$ Serbian Academy of Sciences and Arts, Knez-Mihailova 35, 11000 Beograde, Serbia, milan.sudar1946@gmail.com

* Corresponding author
} 


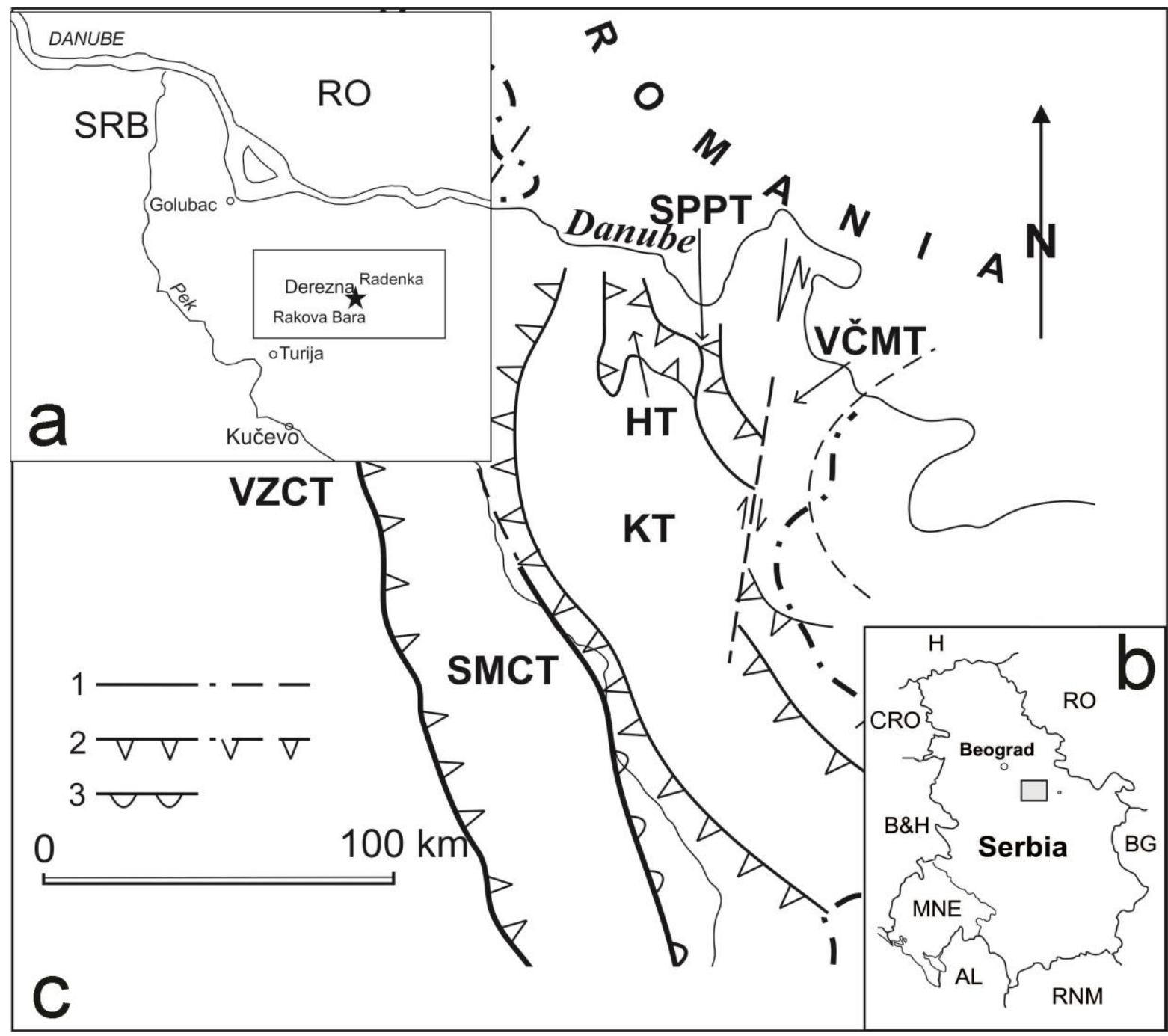

Fig. 1 Position of the investigated area. a Geographic position, northeast of Kučevo town. b Location inside the Serbian teritorry. c Terranes of Central part of Balkan peninsula, between the Moesian plate and the Adriatic Sea (modified, from Karamata and Krstić, 1996); VZCT - Vardar Zone Composite Terrane; SMCT - Serbian-Macedonian Composite Terrane; KT Kučaj Terrane; HT - Homolje Terrane; SPPT - Stara Planina-Poreč Terrane; VČMT - Vrška Čuka -Miroč Terrane. 1, fault (observed and covered); 2 , nappe; 3 , tectonized boundary.

Benthic foraminifera are less frequent. They are represented by: Mayncina sp. (Fig. 8a), Banatia aninensis Schlagintweit \& Bucur (Fig. 8b, c), Moulladella jourdanensis (Foury \& Moullade) (Fig. 8d), small textulariaceans, miliolids and trocholinids [Fig. 6g (T)]

\section{AGE OF THE LIMESTONES}

Banatia aninensis is reported for the first time in Serbia in this study. This species was described initially from upper Barremian deposits of the Southern Carpathians, Romania (Schlagintweit \& Bucur, 2017). For a long time, Moulladella jourdanensis was considered to characterize only the lower Barremian, (e.g. Arnaud-Vanneau, 1980). In fact, its range characterizes the upper Berriasian-lower Barremian interval (Bucur \& Schlagintweit, 2018; Bucur et al., in press). However, the identified dasycladalean algae (e.g., Salpingoporella muehlbergii, S. patruliusi, Korkyrella texana) exclude a prae-Barremian age for these deposits.
REMARKS ON SOME DASYCLADALEAN ALGAE

Salpingoporella patruliusi Bucur, 1985

Fig. 4a-f

1985 Salpingoporella patruliusi n. sp. - Bucur, p. 81, text-fig. 4, pls. 1-3, Barremian-lower Aptian, Pădurea Craiului, Apuseni Mountains, Romania.

1992 Salpingoporella patruliusi Bucur - Bucur, p. 449, text-fig. 1, pl. 2, fig. 1-6, Barremian, Pădurea Craiului, Apuseni Mountains; pl. 2, fig. 7, Barremian-lower Aptian, Reşiţa-Moldova Nouă zone (Southern Carpathians), Romania.

1994 Salpingoporella patruliusi Bucur - Bucur, p. 155, pl. X, fig. 23-24, upper Barremian-lower Aptian, ReşiţaMoldova Nouă zone (Southern Carpathians), Romania. 1999 Salpingoporella patruliusi Bucur - Bucur, p. 56, pl. II, fig. 1-10, Barremian, Pădurea Craiului, Apuseni Mountains, Romania. 


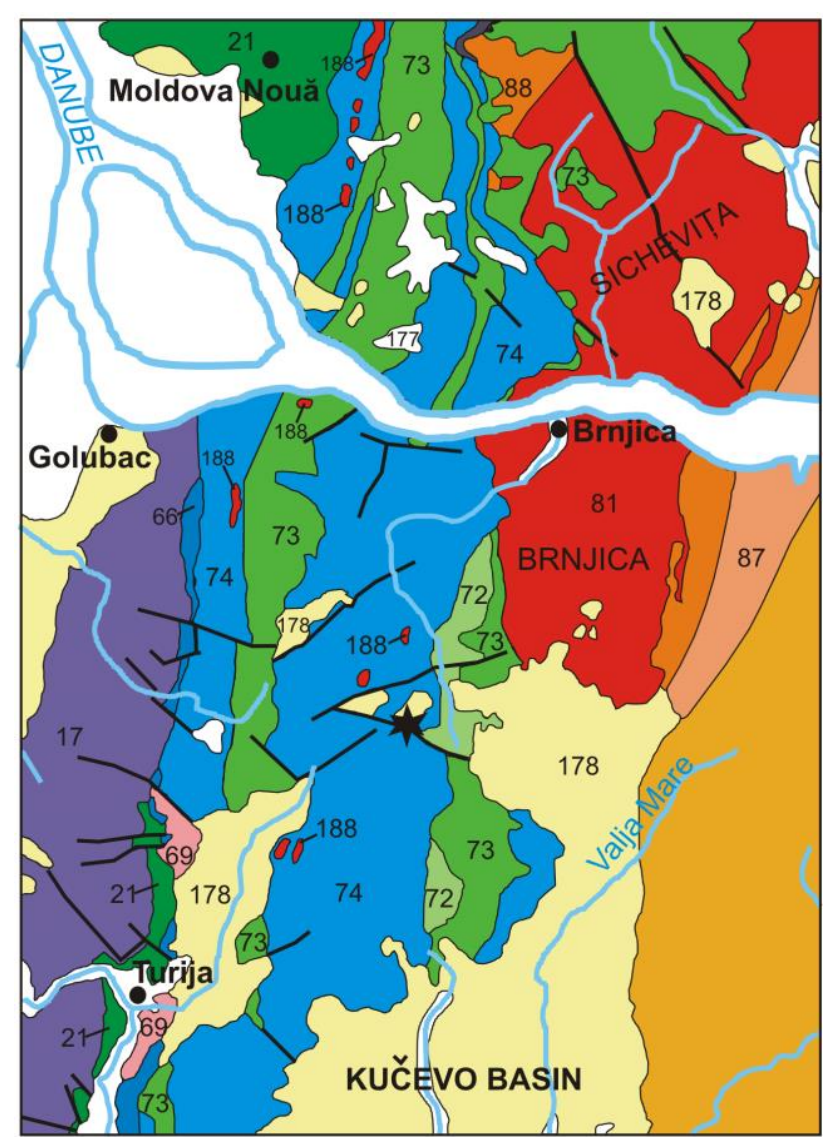

Fig. 2 Excerpt from the Geolocical Map of the CarpathoBalkanides between Mehadia, Oraviţa, Niš and Sophia (Kräutner \& Krstić, 2003). Lower Supragetic Unit (MoniomLocva-Ranovac-Porunica Nappe): 17, Devonan-Lower Carboniferous; 21, Ordovician-Devonian. Getic Unit, Getic Nappe (Kučaj-Ljubaš-Sredna Gora Unit): 72, Albian (Valea Golumbului sandstone); 73, Barremian-Aptian (Urgonian, Plopa and Valea Minişului limestones); 74, Oxfordian-Kimmeridgian, Tithonian, Valanginian-Hauterivian. Post-tectonic sedimentary covers and magmatites: 178, Post-Laramian Miocene; 188, Post-Mesocretaceous Banatitic intrusions. The borehole Derezna is marked by the black star.

2001 Salpingoporella patuliusi Bucur - Bucur \& Cociuba, p. 120, pl. 2, fig. 1-3, lower Barremian, Pădurea Craiului, Apuseni Mountains, Romania.

2001 Salpingoporella patruliusi Bucur - Pop \& Bucur, p. 82, pl. VIII, fig. 9, upper Barremian, Vâlcan Mountains (Southern Carpathians), Romania.

2007 Salpingoporella patruliusi Bucur - Sokač, p. 84, pl. III, fig. 1-3, Upper Barremian, Biokovo Mountains (Dinaric Karst, Croatia).

2008 Salpingoporella patruliusi Bucur 1985 - Sokač \& Grgasović, p. 262, pl. V, fig. 1-6, pl. VI, fig. 1-4, upper Barremian, Dinaric Karst, Croatia.

The specimens identified in Eastern Serbia present clear similarities with the type specimens: a narrow axial cavity with respect to the external diameter of the thallus; ellongated phloiophorous laterals with euspondyl arrangement and tilted to the central stem; calcification forming a distinct sheath around the axis and the laterals.
The general dimensions of the calcareous skeleton of the Serbian specimens and the Romanian type material are also comparable (Table 1).

Table 1 Comparative dimensions of Salpingoporella patruliusi Bucur from the type locality (Pădurea Craiului,

Apusei Mountains, Romania) and Derezna borehole

(Kučaj zone, Carpatho-Balkanides, Eastern Serbia).

\begin{tabular}{|l|l|l|}
\hline & $\begin{array}{l}\text { Type locality } \\
\text { (Pădurea Craiului, } \\
\text { Apuseni Mountains) } \\
\text { (Bucur, 1985) }\end{array}$ & $\begin{array}{l}\text { Borehole Derezna } \\
\text { (Carpatho- } \\
\text { Balkanides, Eastern } \\
\text { Serbia) (this paper) }\end{array}$ \\
\hline $\mathrm{D}$ & $1.10-2.30($ mean 1.48) & $1.10-2.40(1.49)$ \\
\hline $\mathrm{d}$ & $0.11-0.28(0.21)$ & $0.20-0.45(0.30)$ \\
\hline $\mathrm{d} / \mathrm{D}$ & $0.10-0.24(0.15)$ & $0.17-0.28(0.20)$ \\
\hline $\mathrm{l}$ & $0.56-1.00(0.77)$ & 0.55 \\
\hline $\begin{array}{l}\mathrm{p} \\
(\text { dist.) }\end{array}$ & $0.16-0.31(0.22)$ & 0.20 \\
\hline $\mathrm{h}$ & $0.22-0.28(0.26)$ & 0.26 \\
\hline $\mathrm{w}$ & $7-9$ & $7-8$ \\
\hline
\end{tabular}

Initially, the age of the limestones from the type locality (Pădurea Craiului) was attributed to the Barremian-lower Aptian. Subsequently, Bucur \& Cociuba (2001) reassigned it to the lower Barremian. It is difficult to estimate the age of the specimens from the ReșițaMoldova Nouă zone (Bucur, 1994). However, a late Barremian age could be presumed (the lower part of the Valea Minișului Formation). In the Vâlcan Mountains (Pop \& Bucur, 2001), Salpingoporella patruliusi is associated with Montseciella arabica Henson, an orbitolinid that characterizes the upper Barremian to lowermost Bedoulian (Schroeder et al., 2010, fig. 3). Finally, Sokač \& Grgasović, (2008) indicate a late Barremian age for the Dinaric Karst limestones containing Salpingoporella patruliusi. Summarizing, Salpingoporella patruliusi is well known from Barremian strata.

Similiclypeina aff. somalica Conrad, Peybernès \& Masse, 1983

Fig, 5h(Ss)

\section{Remarks}

This alga was first illustrated by Bucur (1993, pl. 3, fig. $7,9 \mathrm{~b}, 10,12-25)$ from limestones located in the median part of the Reșiţa-Moldova Nouă zone. It was described as a species which is similar to Clypeina somalica (Conrad, Peybernès \& Masse, 1983), but with generally smaller dimensions, and was attributed to the genus Similiclypeina Bucur, 1993. The same alga was illustrated by Bucur et al. (2000, pl. VII fig. 19-24) from the eastern Pontides (Turkey). The specimen identified in Eastern Serbia has dimensional values within the variation range of the specimens described from the Reşiţa-Moldova Nouă Zone by Bucur (1993) and the Kirkaova section, Kale- 
Table 2. Comparative dimensions of Similiclypeina aff. somalica from the Reşiţa Moldova Nouă zone (Southern Carpathians, Romania), Kirkaova (Kale-Gmümüshane, NE Turkey), and the specimen from Derezna borehole (Kučaj zone, Carpatho-Balkanides, Eastern Serbia).

\begin{tabular}{|l|l|l|l|}
\hline & $\begin{array}{l}\text { Reşiţa-Moldova Nouă } \\
\text { zone (Sothern Carpathians, } \\
\text { Romania) (Bucur, 1993) }\end{array}$ & $\begin{array}{l}\text { Kirkaova (Kale-Gümüshane, } \\
\text { NE Turkey) (Bucur et al., } \\
2000)\end{array}$ & $\begin{array}{l}\text { Borehole Derezna (Carpa- } \\
\text { tho-Balkanides, Eastern } \\
\text { Serbia) (this paper) }\end{array}$ \\
\hline $\mathrm{D}$ & $0.36-0.54$ & $0.35-0.50$ & 0.45 \\
\hline $\mathrm{d}$ & $0.16-0.23$ & $0.14-0.20$ & 0.25 \\
\hline $\mathrm{d} / \mathrm{D}$ & $0.30-0.46$ & 0.40 & 0.55 \\
\hline $\mathrm{l}$ & $0.19-0.23$ & $0.15-0.20$ & $0.13-0.20$ \\
\hline $\mathrm{p}$ (dist.) & $0.028-0.10$ & $0.05-0.10$ & $0.065-0.11$ \\
\hline $\mathrm{h}$ & $0.07-0.09$ & $0.07-0.08$ & $0.065-0.098$ \\
\hline
\end{tabular}
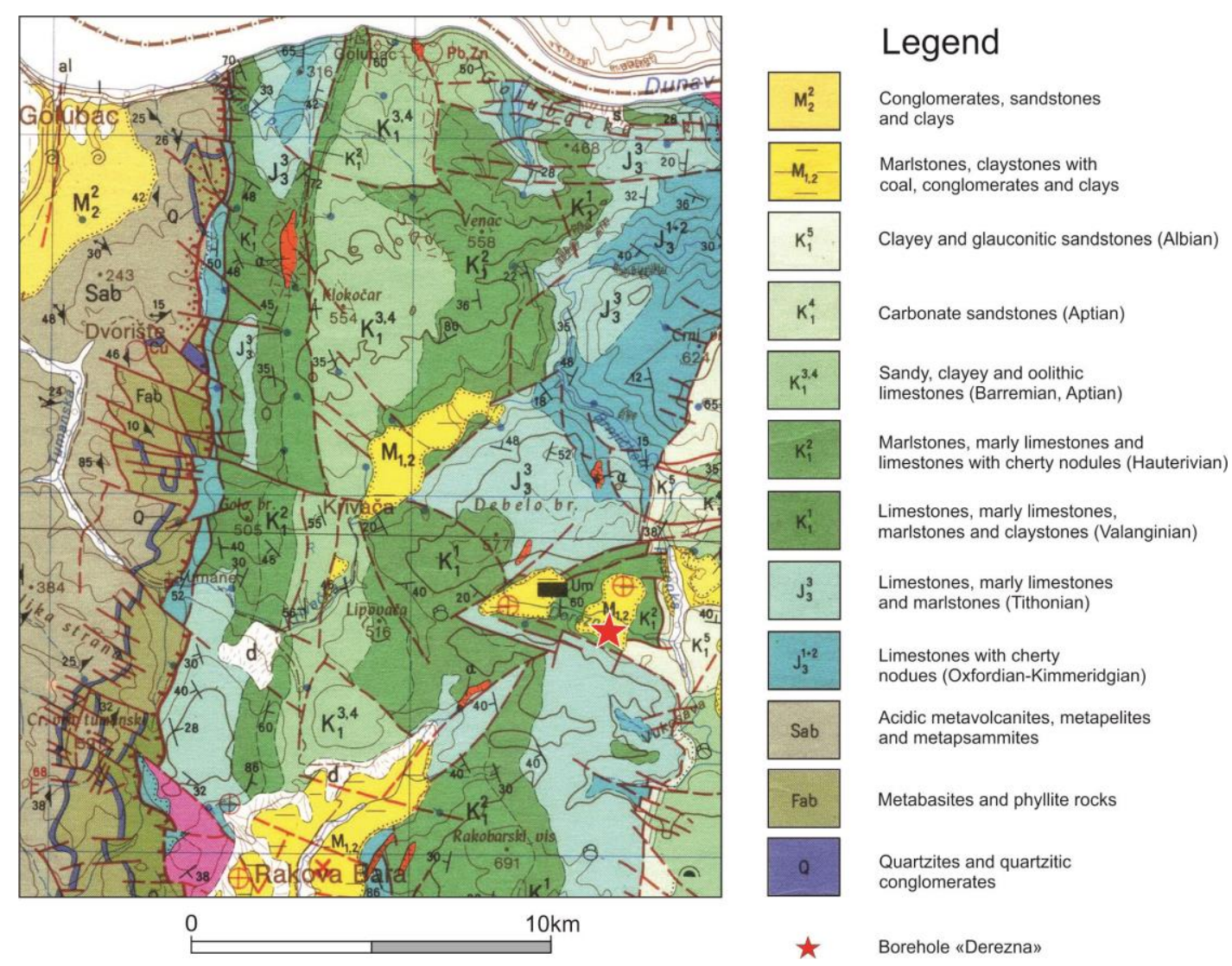

Fig. 3 Excerpt from the Basic Geological Map, 1:100 000, Sheet Kučevo (Kalenić \& Hadži-Vuković, 1980). The borehole Derezna is marked by the red star.

Gümüshane region, NE Turkey (Bucur et al., 2000) (see Table 2).

The genus Similiclypeina was introduced by Bucur (1993) in order to reunite the Clypeina-like dasycladaleans which contain non-spaced whorls that touch each other and are often vertically welded. The genus diagnosis was the following (Bucur, 1993, p. 105): „Thallus made up of overlapping whorls of primary ramifications. Ramifications slightly tilted with respect to the axial cavity, welded at their proximal part and, usually, loose at their distal end. Overlapping whorls touching one another, partly welded into a more or less compact calcareous sheath". Some species doubtfully attributed to the genus Clypeina Michelin (e.g., Clypeina? alrawii Radoičić, 1978; Clypeina? somalica Conrad et 6 al., 1983) have been transfered to the genus Similyclypeina, and a new species, Similiclypeina conradi was introduced (Bucur, 1993).

Sokač (1996) created the genus Piriferella with Piriferella spinosa as type species from the Lower Cretaceous of Croatia. He introduced the species Clypeina somalica in the new combination as Piriferella somalica. According to Sokač (1996, p. 29): „By the arrangement and density of branches and their independent mode of growth, all of which results in a similar general appearence of the thallus, Piriferella nov. gen. comes more closely to Similyclypeina, which is however, characterized by Actinoporella type ramifications (i.e., gradually widening toward exterior) and by vertically flatened coronas." We have to underline 

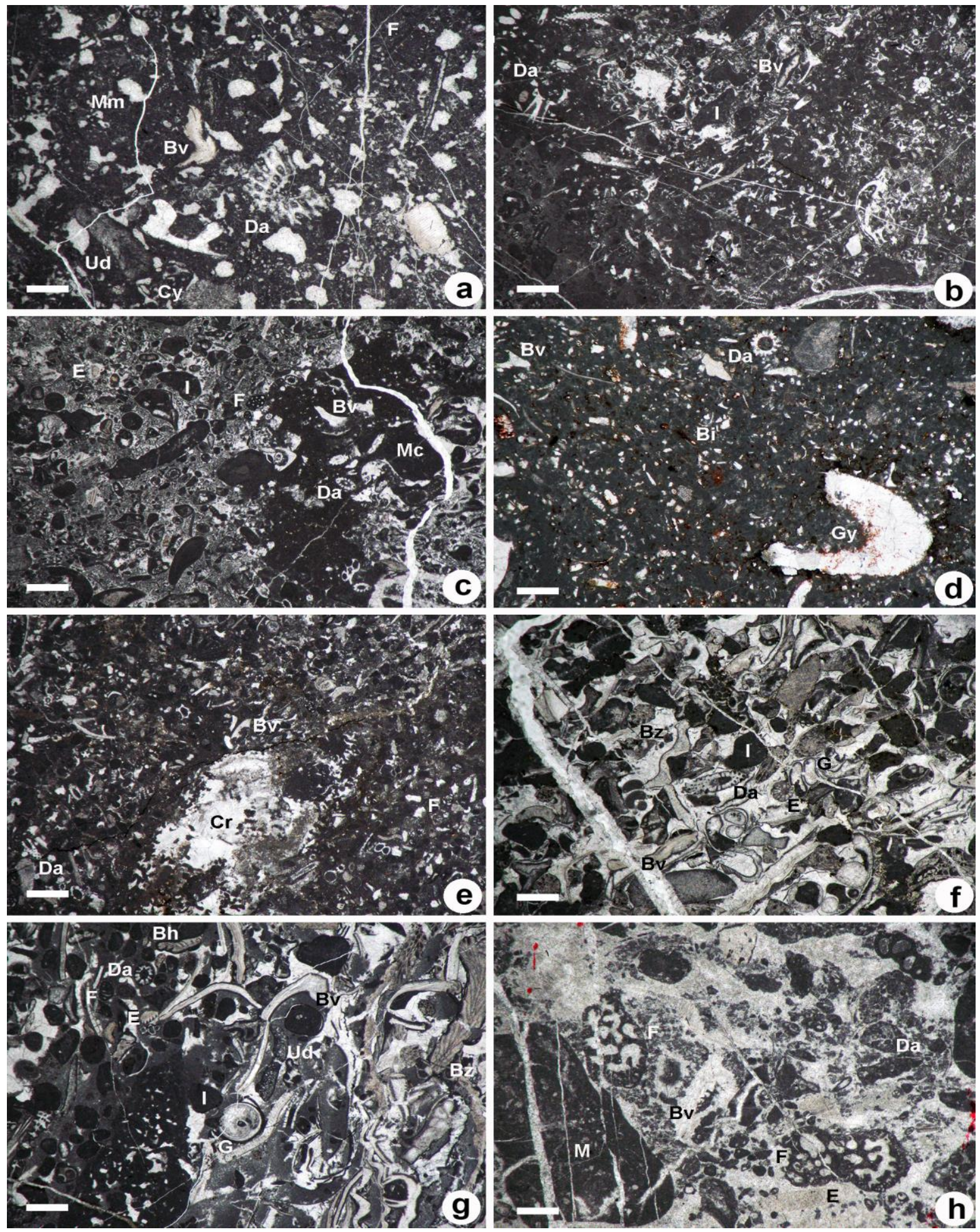

Fig. 4 Microfacies. a Fenestral wackestone with dasycladalean (Da) and udoteacean (Ud) algae, bivalve (Bv) fragments, cyanobacteria (Cy), and foraminifera (F). Some bioclasts are bound by a microbial mass (Mm); thin section RR4834. b Wackestone to packstone with frequent dasycladalean algae (Da), bivalve (Bv) fragments, foraminifera (F), and frequent micritic intraclasts (I); thin section RR4835. c Packstone-grainstone with dasycladalean algae (Da), small bivalve (Bv) and echinoderm (E) fragments, foraminifera $(\mathrm{F})$, and frequent intraclasts (I); Large micritic clasts $(\mathrm{Mc})$ probably resulting from the microbial binding of different small clasts; thin section RR4836. d Packstone with numerous small bioclasts (Bi), rare larger bivalve (Bv) fragments, dasycladalean (Da) and gymnocodiacean (Gy) algae; thin section RR4837. e Packstone recrystallized corals (Cr), bivalve (Bv) fragments, rare foraminifera (F), and frequent dasycladalean (Da) algae; thin section RR4838. f Coarse grainstone with bivalve $(\mathrm{Bv})$, echinoderm $(\mathrm{E})$, bryozoan $(\mathrm{Bz})$, and gastropod $(\mathrm{G})$ fragments, dasycladalean (Da) algae, and micritic intraclasts (I) thin section RR4839. g Coarse packstone to grainstone with bivalve (Bv), echinoderm (E), bryozoan (Bz), brachiopod (Bh), and gastropod $(\mathrm{G})$ fragments, dasycladalean $(\mathrm{Da})$ and udoteacean $(\mathrm{Ud})$ algae, rare foraminifera $(\mathrm{F})$, and micritic intraclasts (I); thin section RR4840. h Coarse grainstone-rudstone with large incrusting foraminifera (F), bivalve (Bv) and echinoderm (E) fragments, dasycladalean (Da) algae, and large clasts with micritic-microbial structure (M); thin section RR4841. Scale bar is $1 \mathrm{~mm}$. 

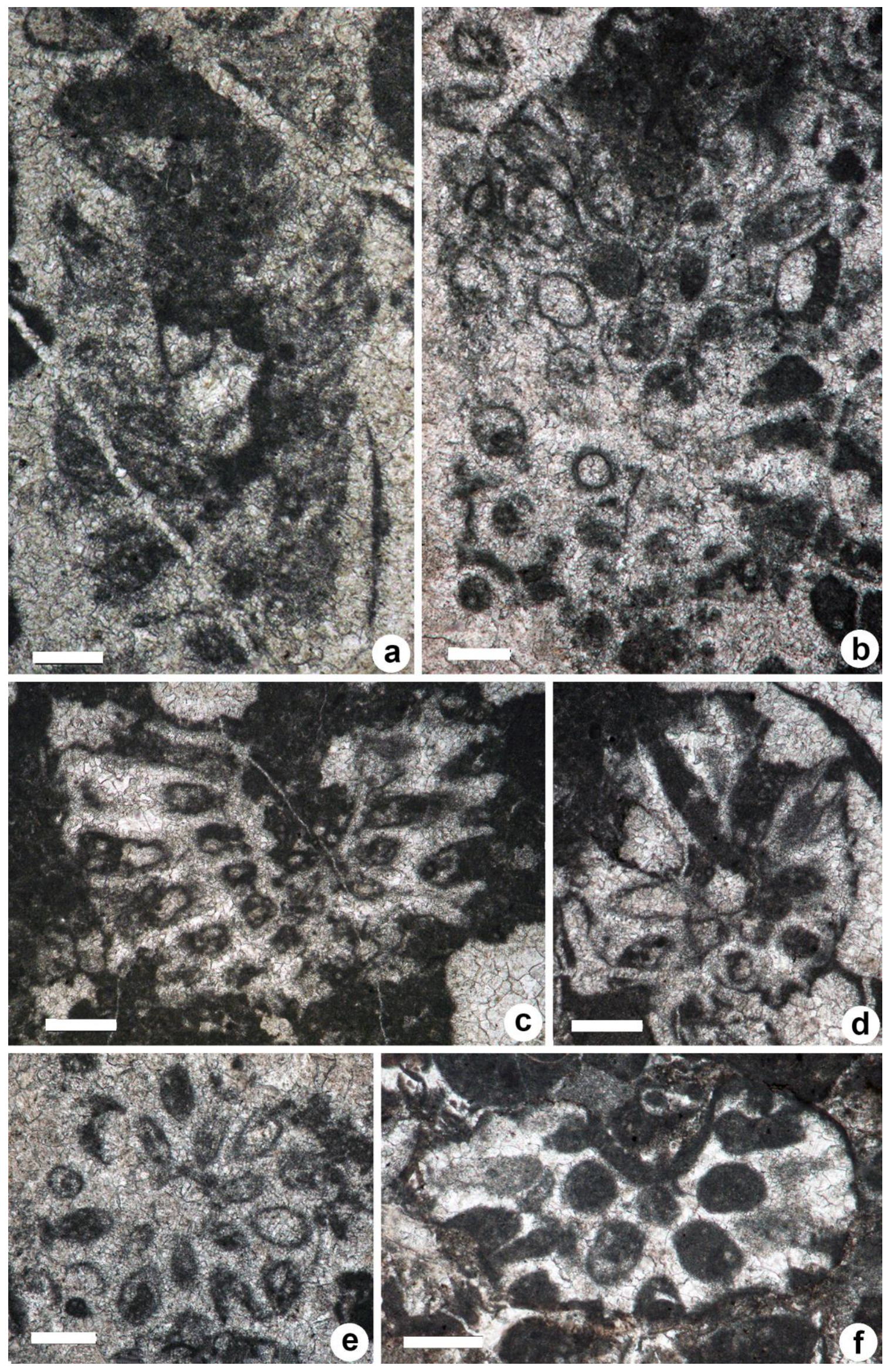

Fig. 5 Calcareous algae. a-f Salpingoporella patruliusi Bucur. a, longitudinal, slightly oblique section; thin section RR4841. b, c, f, oblique tangential sections; thin section RR4841(b), RR4834(c) and RR4840 (f). d, transverse-oblique section; thin section RR4834. e, transverse section; thin section RR4841. Scale bar is $0.25 \mathrm{~mm}$. 

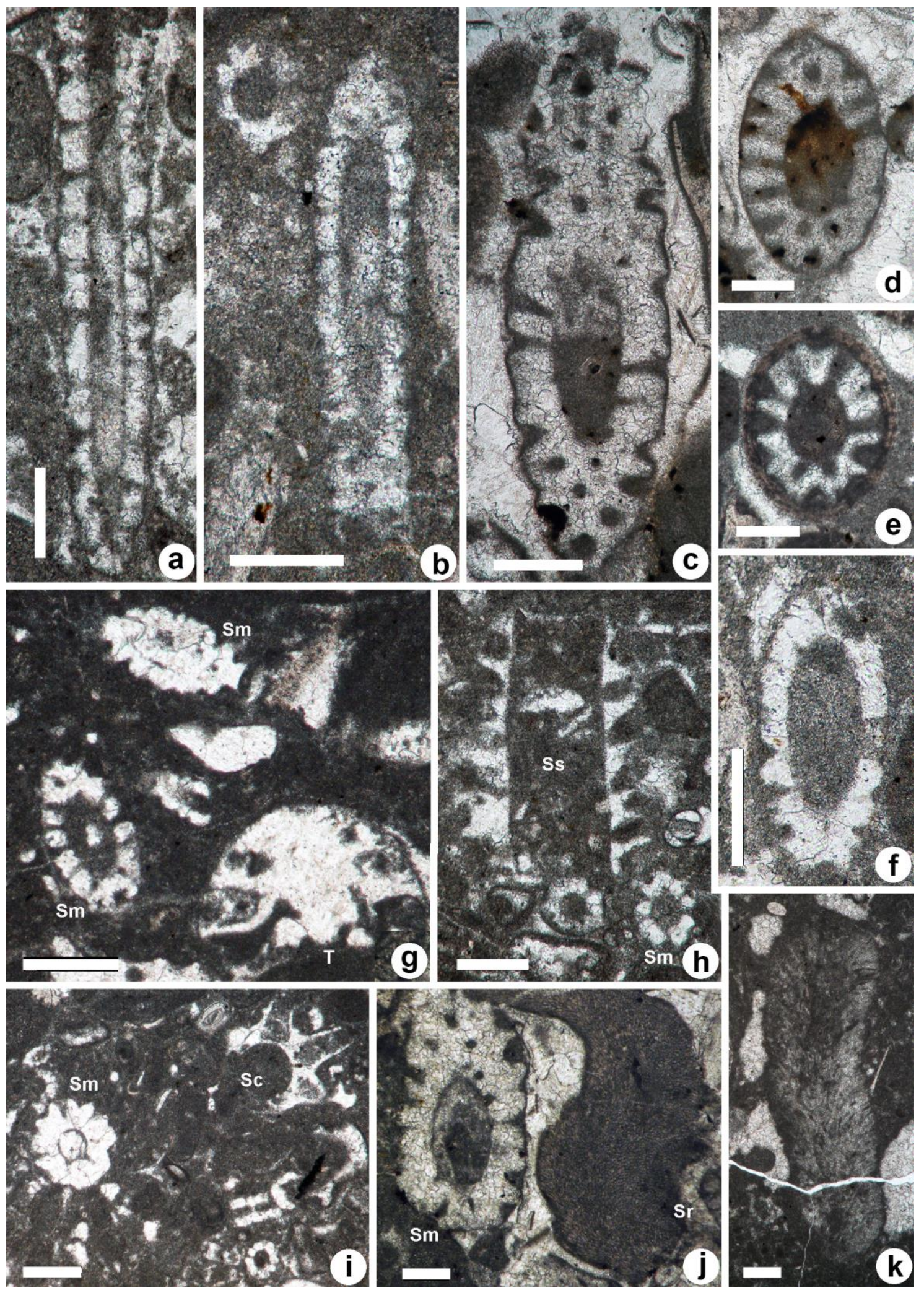

Fig. 6 Calcareous algae. a-c, f Salpingoporella muehlbergii (Lorenz); a, longitudinal section, thin section RR4835; b, longitudinal-slightly oblique, and transverse sections; thin section RR4838; c, f oblique sections; thin sections RR4839 (c) and RR4838 (f). d, e Salpingoporella cf. muehlbergii (Lorenz); thin RR4839 (d) and RR4840(e). g Salpingoporella muehlbergii (Lorenz) (Sm) oblique section, and foraminifer trocholinid (T); thin section RR4836. h Similiclypeina aff. somalica Conrad, Peybernès \& Masse (Ss) longitudinal section, and Salpingoporella muehlbergii (Lorenz) (Sm) transverse section; thin section RR4835. i Salpingoporella muehlbergii (Lorenz) (Sm) transverse section, and Similiclypeina conradi Bucur (Sc) transverse-oblique section; thin section RR4835. j Salpingoporella muehlbergii (Lorenz) (Sm) oblique section, and Sporolithon rude (Lemoine) (Sr); thin section RR4839. k Arabicodium sp.; thin section RR4834. Scale bar is $0.25 \mathrm{~mm}$. 
here that in the diagnosis of the genus Similiclypeina (Bucur, 1993, p. 105), no information is given on the presence of Actinoporella type ramifications (i.e., laterals), or possible coronas. Further comments on the genus Similyclypeina are made by Sokač, 1996 at page 30 where he describes „Piriferella somalica“ stating: „Therefore, Similyclypeina would include forms with different characteristics: forms with horizontally, elongated corona- or vestibule-like swellings in the proximal part of the ramifications ( $S$. conradi and $S$ ? iustiniani), forms with no such swellings at all (S. alrawii and S. somalica) and forms with two types of secondary ramifications, one growing out from the cylindrical stalk of the thallus (sic!), another on the primary branches ( $S$.

pupnatensis). As basal swelling of ramifications is generally agreed to be crucial for distinguishing Actinoporella from Clypeina, and thus became, by general consensus, a criterion of generic rank, it would be illogical to erect a genus that would unite forms with and without such an important feature“. In fact, Sokač (1996) transfers the characterstics of the species $S$. conradi to the entire genus without taking into account the given diagnosis of genus Similiclypeina. In addition, he mentions corona located inside the whorls, between the laterals. The enlarged portion at the base of the laterals of $S$. conradi is interpreted as two coronas. Bucur et al. (2000, p. 452) commented on these aspects, showing that (translated from French): „The presence of "corona" in Similiclypeina conradi (type species of the genus Similiclypeina) underlined by Sokač (1996), who consider that the author neglected this character in the generic diagosis is, in our opinion, inacceptable. Following Berger and Kaever (1992) „,.. Corona superior $=$ the total of the circularly arranged processes at the upper side of a cap at the insertion of the cap rays into the stalk (main axis). Each cap ray bears one corona segment, each corona superior segment bears a speciesspecific number of protuberances... Corona inferior = the total of circulary arranged processes at the underside of the cap surrounding the insertion of the cap rays into the stalk. If a corona inferior is present, one corona process belongs to each cap ray. The corona inferior is always devoid of protuberances“. Starting from this definition we can ask how could a "corona" be formed between the laterals of the same verticil? Because it is not corona, the specific aspect of the laterals of $S$. conradi was not considered as a character of generic value, and was not mentioned in the genus diagnosis..." In other words, if we follow the logic of the existence of corona on the lateral basal side of the laterals, we have to speak about „left corona“ and ,right corona“, an assumption that does not correspond to any of the known characteristics of dasycladalean algae. Otherwise, the characteristic aspect of the laterals of Similiclypeina conradi could result from the presence of non-calcified reproductive cysts in the lower part of the laterals. Regarding Humiella? pupnatensis Sokač, 1987, [synonymized by Bucur (1993) with Similiclypeina somalica], we question the existence of "secondary ramifications" starting directly from the stalk. Probably the author (Sokač, 1996) was refering to sterile and not secondary ramifications. In addition, Sokač (1987) speaks about secondary short ,ramifications, located in the distal part of the primary fertile ,ramifications,,. However, these secondary laterals are difficult to observe and they may correspond to simple irregularities of the calcareous sleeve.

The genus Piriferella (Sokač, 1996) was created based on the typical ,,pyrifer,, (pyriform would be better) shape of its laterals (Sokač, 1996, p. 28). In fact, neither the type species ( $P$. spinosa) nor „P. somalica“ are characterized by typical pyriform laterals. The laterals of Piriferella spinosa have a variable shape that ranges from ovoidal to vesiculiform or slightly phloiophorous/rarely pyriform (see Sokač, 1996, pl. XXI). Otherwise, if we consider the laterals of Piriferella as typical pyriform then this genus would become a junior synonym of the Triassic genus Physoporella Steinmann, 1903 emend. Grgasović 1995 (see also Bucur et al., 2000, p. 452). Based on the considerations stated above on the genus Similiclypeina, Bucur (2000) transfered the species Heteroporella? paucicalcarea Conrad, 1970 to the genus Similiclypeina in the new combination Similiclypeina paucicalcarea (Conrad). Controversies concerning the two genera (Similiclypeina and Piriferella) and their attributed species continued in the following years. In an abstract published in the abstract volume of the 6th regional symposium on calcareous algae, held in Milano, Conrad et al. (2009) restricted the componence of the genus Similiclypeina to the type species. All the above mentioned species were attributed to the genus Piriferella. Moreover, the authors (Conrad et al., 2009) proposed the synonymization of the species Clypeina somalica Conrad, Peybernès \& Masse, 1983, Piriferella spinosa Sokač, 1996, and Salpingoporella verrucosa Sokač, 1996 under the combination Piriferella somalica (Conrad, Peybernès \& Masse). On the poster presented by the same authors (Conrad et al., 2009) during the Milano symposium the species Heteroporella? paucicalcarea was also transfered to the genus Piriferella in the combination Piriferella paucicalcarea (Conrad). Finally, the author's initiative (Conrad et al., 2009) to publish a paper on this subject was abandoned. However, this approach was accepted without any objections by Bucur (2011), at least for Piriferella paucicalcarea. It was rightly rejected by Granier (2013). Granier ascribed the species Clypeina somalica to the genus Holosporella (see also Granier, 1992), restricted the interpretation of the genus Similiclypeina to its type species ( $S$. conradi) and ascribed the species Heteroporella? paucicalcarea to the genus Clypeina in the new combination Clypeina paucicalcarea (Conrad). In fact, the shape of the laterals of Heteroporella? paucicalcarea has nothing to do with the pyriform shape. Thus, even if one accepts the well establishment of the genus Piriferella, the species paucicalcarea cannot be assigned to this genus. 

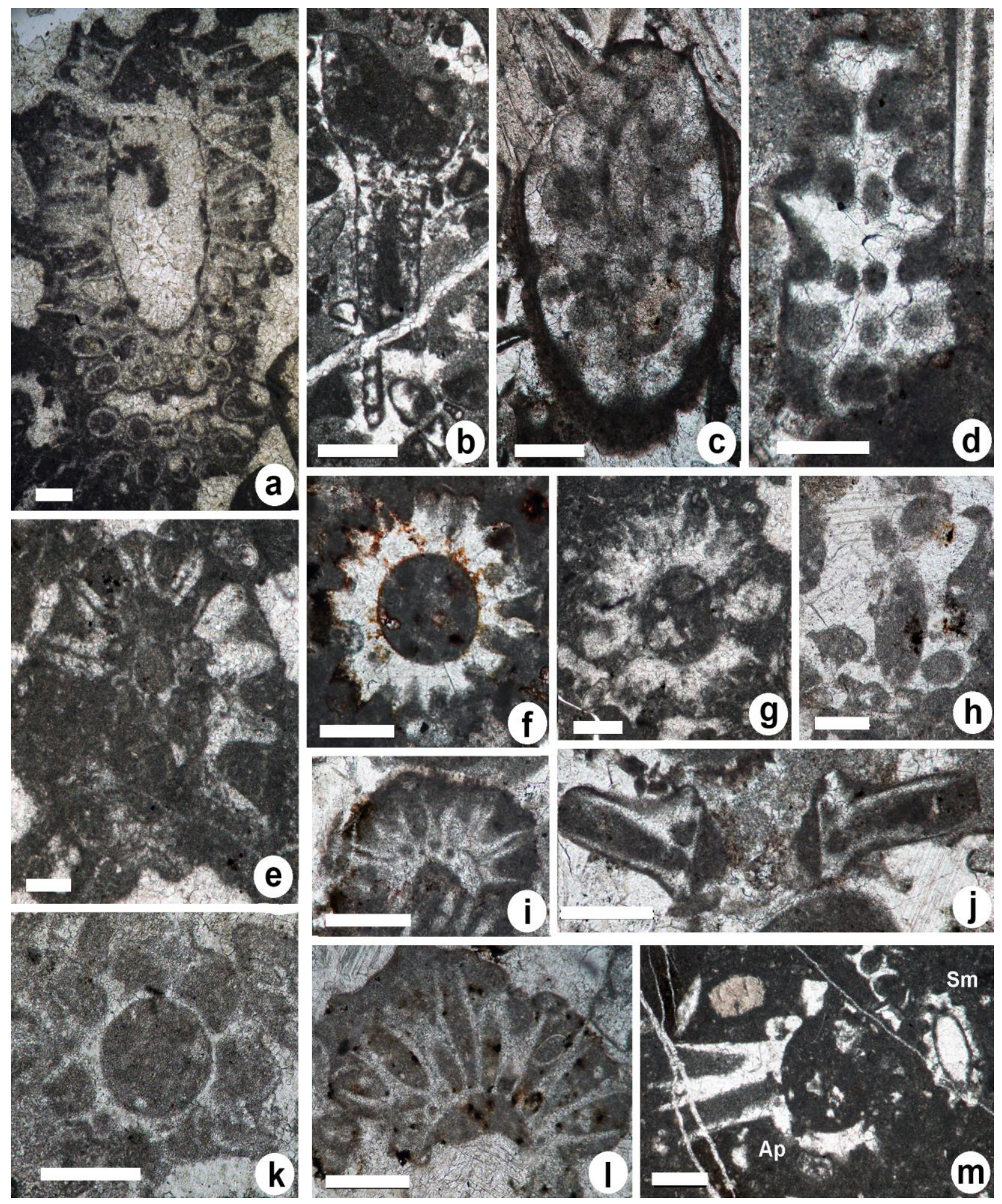

Fig. 7 Calcareous algae. a Milanovicella? sp., oblique section; thin section RR4834. b, c Korkyrella texana (Sokač); b, longitudinal section showing the lower stalk and part of the upper cap; thin section RR4835; c, oblique section of a cap; thin section RR4840. d Salpingoporella biokovensis (Sokač), longitudinal-tangential section; thin setion RR4840. e-h Clypeina div. sp. e, oblique section; thin section RR 4834; f, g, transverse sections; thin section RR4837 (f) and RR4834 (g). i, j, I Actinoporella podolica (Alth), oblique sections; thin section RR4840 (i, j) and RR4839 (1). k Similiclypeina conradi Bucur, transverse section; thin section RR4835. m Actinoporella podolica (Alth) (Ap) and Salpingoporella muehlbergii Lorenz (Sm), oblique sections; thin section RR4835. Scale bar is $0.25 \mathrm{~mm}$. 

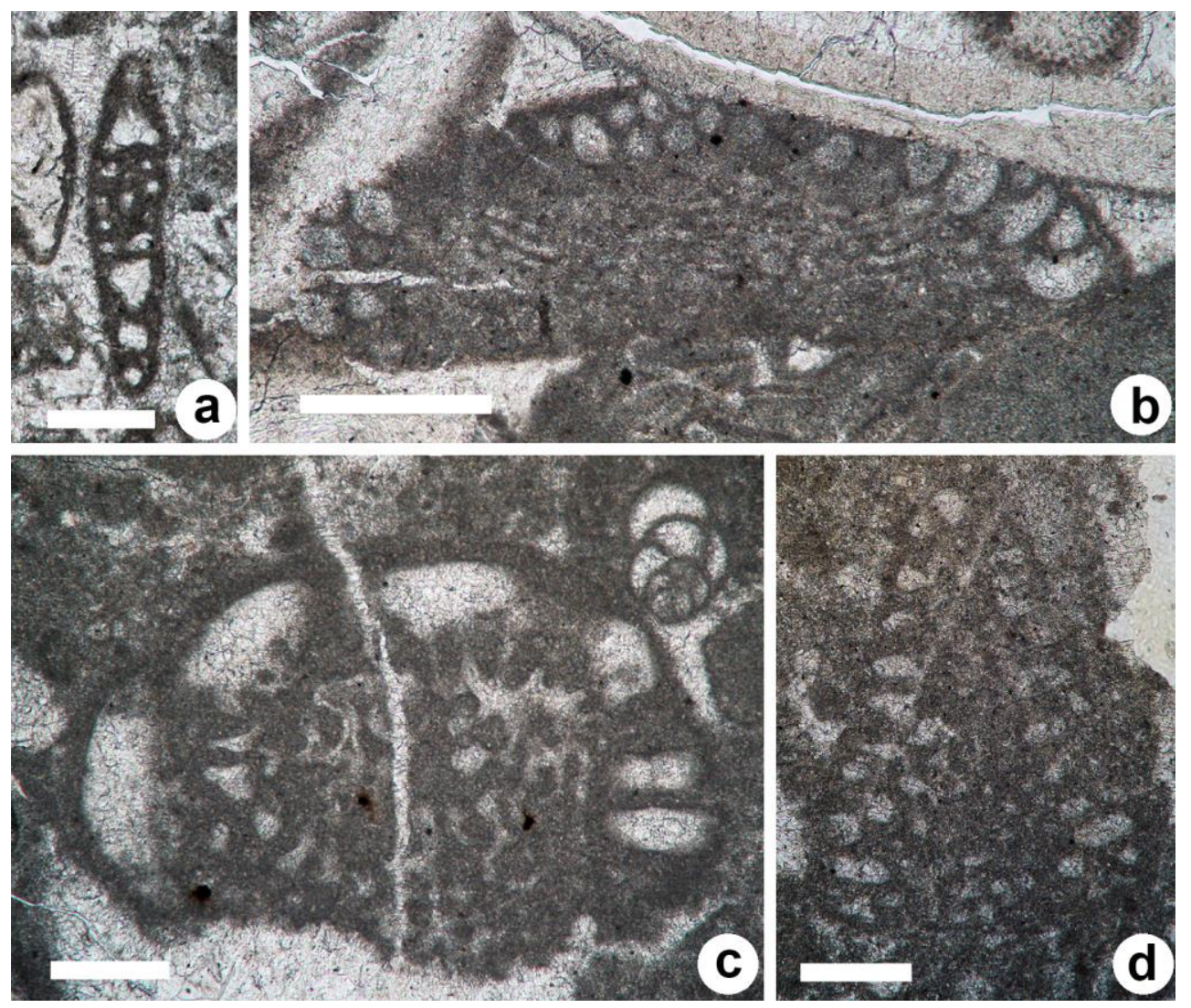

Fig. 8. Foraminifera. a Mayncina sp., subaxial section; thin section RR4836. b, c Banatia aninensis Schlagintweit \& Bucur; b, axial section; thin section RR4840; c, transverse-oblique section; thin section RR4834. d Moulladella jourdanensis (Foury \& Moullade), subaxial section; thin section RR4834. Scale bar is $0.25 \mathrm{~mm}$.

It is obvious that even Granier (2013) eludes the diagnosis of the genus Similiclypeina (Bucur, 1993) by interpreting it in the sense of the type species, $S$. conradi. The author (Granier, 2013, p. 60) mentions: „...it would be safer to revert to Bucur's (2000) view: Heteroporella? paucicalcarea is a Clypeina-like species the verticils of which are set rather close together. Because the species lacks the typical pattern of the laterals in Similiclypeina conradi Bucur, 1993, it should "naturally" be relocated among the representatives of Clypeina (Michelin, 1845)." Or, the reason to erect the genus Similiclypeina (Bucur, 1993) was to group together species with Clypeina-like verticils but with closed-set verticils. Frequently, Clypeina species are preserved as separate whorls spread in the sediment. The large distance between successive whorls leads to a rare potential of preservation within the succession (see the example of Clypeina besici Pantic in Granier \& Deloffre, 1994 (Pantić, 1965), or Clypeina helvetica Morellet \& Morellet, 1918 from Eocene (cf. Schlagintweit et al., 2013); see also Clypeina in Genot, 1980; 1987; 2009, and in Granier \& Lethier, 2019). Вy contrast, Heteroporella? paucicalcarea presents a compact skeleton since its whorls are welded in their vertical succession (see for instance the detached specimens in Bucur, 2011, pl. 1, fig. 6). As a consequence, the generic affiliation of these controversial species still remains open.

\section{CONCLUSIONS}

1. The limestones crossed by the Derezna borehole contain mainly muddy facies types (wackestone, wackestone-packstone or packstone) and subordinate coarse grainstone. All these varieties are relatively rich in calcareous algae (especially dasycladaleans).

2. Salpingoporella patruliusi is recorded with a high frequency within the calcareous algae inventory. The entire association contains species known from the Barremian-Aptian interval.

3. The foraminiferal association is scarce and contains species (Moulladella jourdanensis, Banatia aninensis) that indicate a Barremian age. Banatia aninensis is identified for the first time in Serbia, and second time outside its type locality.

4. This micropaleontological association is very simillar to the one identified in the ReșiţaMoldova Nouă zone (Bucur, 1994, 1997; Schlagintweit \& Bucur, 2017), a fact indicating that the Reșița-Moldova Nouă sedimentary basin (Getic Nappe) continues south of the Danube into the Kučaj zone. 
5. Two algae (Salpingoporella patruliusi and Similiclypeina aff. somalica) are identified for the first time in Serbia. They allow us to make some paleontological and taxonomical remarks concerning the status of the genera Similiclypeina Bucur, 1993 and Piriferella Sokač, 1996. The way these algae were interpreted by various authors in the last decades indicates that their status still remains an open issue.

\section{AKNOWLEDGEMENTS}

We thank the two reviewers, Felix Schlagintweit and Mike Kaminski, as well as the editor Iuliana Lazăr for their rematks and corrections which helped to improve the manuscript. The paper is a contribution to the bilateral cooperation between the Romanian Academy and the Serbian Academy of Sciences and Arts.

\section{REFERENCES}

Arnaud-Vanneau, A., 1980. Micropaléontologie, paléoécologie et sédimentologie d'une plate-forme carbonate de la marge passive de la Tethys: L'Urgonien de Vercors septentrional et de la Chartreuse (Alpes occidentales). Géologie Alpine, Mémoire 11 (1-2): 1-874.

Berger, S. \& Kaever, M. J., 1922. Dasycladales. An illustrated monograph of a fascinating algal order. Georg Thieme Verlag, Stuttgart, 247 pp.

Bucur, I.I., 1985. A new dasycladacean alga in the Urgonian limestones from Pădurea Craiului (Apuseni Mountains): Salpingoporella patruliusi n. sp. Révue Roumaine de Géologie, Géophysique et Géographie, Géologie 29: 81-84.

Bucur, I.I., 1992. Revised description of some dasyclad species from the Romanian Lower Cretaceous. Révue de Paléobiologie, 11(2): 447-461.

Bucur, I.I., 1993. Some new or poorly known calcareous algae (Dasycladales, Gymnocodiaceae) in the Lower Cretaceous deposits from the Reşiţa-Moldova Nouă zone (Southern Carpathians, Romania). Revista Española de Micropaleontologia, 25(1): 93-126.

Bucur, I.I., 1994. Algue calcaires de la zone de ReşiţaMoldova Nouă (Carpathes Méridionales, Roumanie). Revue de Paléobiologie, 13(1): 147-209.

Bucur, I.I., 1997. Formaţiunile mezozoice din zona Reşiţa-Moldova-Nuă (Munţii Aninei şi estul Munţilor Locvei). Presa Universitară Clujeană, Cluj-Napoca, $214 \mathrm{pp}$.

Bucur, I.I., 2000. Lower Cretaceous dasyclad algae from the Pădurea Craiului massif (Northern Apuseni Mountains, Romania). Acta Palaeontologica Romaniae, 2 (1999): 53-72.

Bucur, I.I., 2011. Early Barremian dasycladalean algae from Serre de Beyton (Drôme, SE France). Annalen des Naturhistrorischen Museums in Wien, 113: 619653.
Bucur, I.I. \& Cociuba, I., 2001. Lower Cretaceous algae of Pădurea Craiului. In: Bucur, I.I., Filipescu, S. \& Săsăran, E. (eds) Algae and carbonate platforms in the western part of Romania. $4^{\text {th }}$ Regional Meeting of IFAA, Cluj-Napoca, Romania, August 29-September 5, 2001. Field trip Guidebook, Cluj University Press, pp. 117-126.

Bucur, I.I., Koch, R., Kirmaci, Z. \& Tasli, K., 2000. Les algues Dasycladales du Crétacé inférieur (Calcaire de Berdiga) de Kirkaova (region de Kale-Gümüshane, NE Turkey). Révue de Paléobiologie, 19(2): 435-463.

Bucur, I.I. \& Schlagintweit, F., 2018. Moulladella jourdanensis (Foury \& Moullade, 1966) n.gen, n. comb.: Valanginian-early Barremian larger benthic foraminifera from the northern Neothetyan margin. Acta Palaeontologica Romaniae, 14(2): 45-59.

Bucur, I.I., Sudar, M., Schlagintweit, F., Pleş, G., Săsăran, E., Jovanović, D., Polavder, S. \& Radoičić, R., 2020 (in press). Lowermost Cretaceous limestones from the Kučaj zone (Carpatho-Balkanides, eastern Serbia): new data on their age assignement. Cretaceous Research.

Conrad, M.A., Peybernès, B. \& Masse, J.-P., 1983. Clypeina somalica n. sp., dasycladale nouvelle du Crétacé inférieur de la Plaque Africaine (Rép. de Somalie, Italie méridionale). Annales de la Société géologique du Nord, 103: 93-96.

Conrad, M.A., Schlagintweit, F. \& Bucur, I.I., 2009. Piriferella somalica (Dasycladaceae, calcareous green algae) from Tithonian deposits in the Northern Calcareous Alps - synonymy followed by an emendation of Piriferella Sokač 1996, and Similiclypeina Bucur, 1993. In: Bassi, D., Caragnano, A., Bracchi, V. \& Benzoni, F. (Eds) Abstract book, International Fossil Alage Association $6^{\text {th }}$ Regional Symposium, 1-5 July 2009, Milan-Italy, pp. 26.

Dunham, R. J., 1962. Classification of carbonate rocks according to depositional texture. In: Ham, W. E. (ed.), Classification of carbonate rocks: American Association of Petroleum Geologists Memoir 1, pp. 108121.

Génot, P., 1980. Les Dasycladacées du Paléocène supérieur et de l'Éocène du Bassin de Paris. Mémoires de la Societé Géologique de France, 138:1-40.

Génot, P. (1987) Les Chlorophycées calcaires du Paléogène de'Europe nord-occidentale (Bassin de Paris, Bretagne, Contentin, Bassin de Mons). Thèse de Doctttorat d'Etat, Université de Nantes, 500 pp.

Génot, P., 2009. Cenozoic Dasycladales. A photo-atlas of Lutetian species from French Cenozoic basins. http://paleopolis.rediris.es/cg/CG2009_SP01/index.ht $\mathrm{ml}$

Granier, B., 1992. Les algues et les foraminifères benthiques du Jurassique supérieur et du Crétacé inférieur du Sénégal. Journal of African Earth Sciences, 14(2): 239-253. 
Granier, B., 2013. Heteroporella? paucicalcarea (Conrad, 1970), an Urgonian dasycladalean alga revisited. Carnets de Géologie, Letter 2013/01: 59-65.

Granier, B.R.C. \& Lethier, A., 2019. Aloisalthella, a new genus of fossil Polyphysacean green algae (Chlorophyta, Dasycladales), with notes on the genus Clypeina (Michelin, 1845). Palaeontologia Electronica 22.2.45A 1-20. https://doi.org/10.26879/923.

Kalenić, M., Hadži-Vuković, M. 1980. Basic Geological Map, 1:100 000. Sheet Kučevo (L33-128) Federal Geological Survey, Beograd.

Kalenić, M., Hadži-Vuković, M., Dolić, D., Lončarević, Č., Rakić, M. 1980. Basic Geological Map, 1:100 000. Explanatory Notes, Sheet Kučevo (L33-128), 185. Federal Geological Survey, Beograd.

Karamata, S., Krstić, B. 1996: Terranes of Serbia and neighbouring areas. In: Knežević, V, Đorđević, P. \& Krstić, B. (Eds.). Terranes of Serbia. University of Belgrade and Serbian Academy of Sciences and Arts, 25-40, Belgrade.

Kräutner, H.G., Krstić, B. 2002. Alpine and Pre-Alpine structural units within the Southern Carpathians and the Eastern Balkanides. Proceedings of XVII. Congress of Carpathian-Balkan Geological Association (Bratislava, September 1-4, 2002), Geologica Carpathica, vol. 53, Special Issue, 7 pp.

Kräutner, H.G. \& Krstić, B.P. 2003. Geological map of the Carpatho-Balkanides between Mehadia, Oravita, Niš and Sofia. Geoinstitute, Belgrade.

Pantić, S., 1965. Clypeina besici sp. nov. des sédiments triassiques des Dinarides externs. Geoloski Glasnik, 4: 133-141 (in Serbo-Croatian with French summary).
Pop, G. \& Bucur, I.I., 2001. Upper Jurassic and Lower Cretaceous sedimentary formations from the Vâlcan Mountains (South Carpathians). Studia UBB Geologia, 46(2): 77-94.

Schlagintweit, F. \& Bucur, I.I., 2017. Banatia aninensis n. gen.,n. sp., a new complex larger foraminifer from the upper Barremian of Romania. Cretaceous Research, 75: 23-30.

Schlagintweit, F., Bover-Arnal, T., Menkveld-Gfeller, U. \& Strasser, A., 2013. Clypeina helvetica Morellet \& Morellet, 1918, revisited. A Priabonian (Late Eocene) dasycladalean alga from Diablerets Nappe of the Helvetic Alps, southwestern Switzerland. Facies, 59: 287297.

Sokač, B., 1987. On some controversial Dasyclad genera and species and their stratigraphic position in the Lower Cretaceous deposits of the Dinarides. Geološki Vjesnik, 40: 9-38

Sokač, B., 1996. Taxonomic review of some Barremian and Aptian calcareous algae (Dasycladales) from the Dinaric and Adriatic Karst regions of Croatia. Geologia Croatica, 49(1): 1-79.

Sokač, B., 2007. Extremly rich Upper Barremian dasycladal association - Mali Troglav. In: Grgasović, T. \& Vlahović, I., 2007. $9^{\text {th }}$ International Symposium on Fossil Algae Croatia 2007, Field Trip Guidebook and Abstracts, Croatian Geological Survey, Zagreb, pp. 83-97.

Sokač, B. \& Grgasović, T., 2008. On some Salpingoporella species from the Lower Cretaceous of Dinaric karst. Geologia Croatica, 61(2-3): 251-271. 